\title{
Zeolite H-BEA catalysed multicomponent reaction: One-pot synthesis of amidoalkyl naphthols - Biologically active drug-like molecules
}

\author{
SUNIL R MISTRY ${ }^{\mathrm{a}}$, RIKESH S JOSHI ${ }^{\mathrm{b}}$ and KALPANA C MAHERIA ${ }^{\mathrm{a}, *}$ \\ ${ }^{a}$ Applied Chemistry Department, S V National Institute of Technology, Surat 395 007, India \\ ${ }^{\mathrm{b}}$ Sud Chemie India Pvt. Ltd., Nandesari-391 340, Gujarat, India \\ e-mail: maheria@gmail.com
}

MS received 10 September 2010; revised 2 December 2010; accepted 16 May 2011

\begin{abstract}
Zeolite has been used as an efficient and a novel heterogeneous catalyst for one-pot synthesis of biologically active drug-like molecules, amidoalkyl naphthols. This green route involves multicomponent reaction of 2-naphthol, aromatic aldehydes and amide in the presence of a catalytic amount of zeolite $\mathrm{H}$-Beta (H-BEA) under solvent reflux as well as solvent-free conditions.
\end{abstract}

Keywords. Zeolite; multicomponent reaction; amidoalkyl naphthol; green chemistry.

\section{Introduction}

The use of acidic zeolites in different areas of the organic chemistry has now reached significant levels, not only for the possibility to perform environmentally benign synthesis, but also for the good yields. ${ }^{1}$ Further, zeolites are broadly used in the synthesis of specialty and fine chemicals. They have received an increasing attention because of their tunable acidity and the variety of structures and pore dimensions. The other salient features of zeolite include their low cost and excellent thermal stability which make them economically and environmentally feasible. ${ }^{2}$ The use of zeolites as a catalyst is important in the development of clean technologies, since it avoids the drawbacks of the conventional technologies, mainly environmental pollution and corrosion of the equipment (figure 1).

Multicomponent reactions (MCRs) have attracted considerable attention since an increasing number of organic chemical compounds are formed by multicomponent reactions (MCRs) that convert more than two educts directly into their products by one-pot reactions. Further, they are performed without need to isolate any intermediate during their processes; this reduces time and saves both energy and raw material. They have merits over two-component reactions in several aspects including the simplicity of a one-pot procedure, possible structural variations and building up complex molecules. ${ }^{3}$

One of these MCRs is the preparation of amidoalkyl naphthols. It is worthy to note that by amide hydrolysis

*For correspondence reaction, 1-amidomethyl-2-naphthols can be converted to important biologically active 1-aminomethyl- 2naphthol derivatives. The hypotensive and bradycardiac effects of these compounds have been reported. ${ }^{4}$ The preparation of 1-amidoalkyl-2-naphthols can be carried out by multi-component condensation of aryl aldehydes, 2-naphthol and acetonitrile or amide in the presence of Lewis or Brønsted acid catalysts such as montmorillonite $\mathrm{K} 10$ clay, ${ }^{5} \mathrm{HClO}_{4}-\mathrm{SiO}_{2},{ }^{6}$ iodine, ${ }^{7}$ heteropolyacids, ${ }^{8} p$-TSA,${ }^{9}$ sulfamic acid, ${ }^{10}$ and cationexchange resins. ${ }^{11}$ However, some of these methods associated with prolonged reaction time, toxicity and low yields of desired product. Further, when a solid aldehyde or high amounts of catalyst is used, an organic solvent such as dichloroethane is needed. ${ }^{10}$ In this context, there is growing interest in development of clean processes involving green catalysts. Increasing demand for environmentally benign procedures with heterogeneous and reusable catalys $\mathrm{t}^{12}$ encourage us to develop a safe alternate method for the synthesis of amidoalkyl naphthols using acidic zeolite. To the best of our knowledge, no reports are available on the synthesis of amidoalkyl naphthol using zeolite as catalyst (scheme 1).

\section{Experimental}

\subsection{Materials and methods}

The composition of anhydrous Na-BEA zeolite was obtained from Sud-Chemie India Pvt Ltd., India. The 


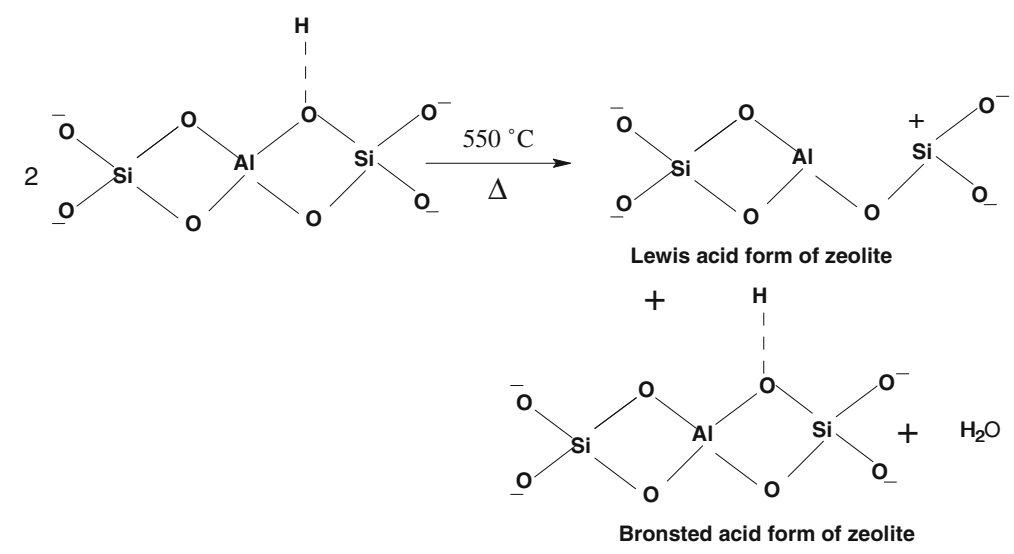

Figure 1. Lewis and Bronsted acidic form of zeolite.

$\mathrm{H}$-form zeolite was prepared by ion exchange of the Naform sample with aqueous solution of $\mathrm{NH}_{4} \mathrm{NO}_{3}(1 \mathrm{M})$ or alkali metal acetate, followed by drying and calcination at $823 \mathrm{~K}$.

The X-ray diffractogram $\left(2 \theta=5-65^{\circ}\right)$ were obtained on X-ray diffractometer (D8 Advanced Brucker AXS, Germany) with $\mathrm{Cu}-\mathrm{K}_{\alpha}$ radiation and nickel filter. Surface area measurement (BET method) was carried out on Micromeritics Gemini at $196^{\circ} \mathrm{C}$ using nitrogen adsorption isotherms. Acidity of zeolites were determined on Micromeritics Chemisorb 2720, by a temperature programmed desorption of ammonia. Ammonia was chemisorbed at $120^{\circ} \mathrm{C}$ and then desorption was carried out up to $700^{\circ} \mathrm{C}$ at heating rate of $10^{\circ} \mathrm{C} / \mathrm{min}$.

The solvents were distilled before use. All reagents used were of analytical grade. NMR spectra were recorded on a Varian $200 \mathrm{MHz}$. IR spectra were run on a (FT-IR) (Shimadzu make, model $8400 \mathrm{~S}$ ) using $\mathrm{KBr}$ powder. Mass spectra were recorded on VG micromass $7070 \mathrm{H}$. The purity of the substances and the progress of the reactions were monitored by TLC on silica gel.

\subsection{Procedure for the synthesis of amidoalkyl naphthols}

To a mixture of 2-naphthol (1 mmol), aldehydes $(1 \mathrm{mmol})$ and acetamide $(1.2 \mathrm{mmol})$, effective amount of zeolite H-BEA was added. The mixture was stirred under thermal solvent-free condition at $120^{\circ} \mathrm{C}$ in oil bath for $5-7 \mathrm{~min}$ and the reaction was followed by TLC. After completion of reaction, mass was cooled to $25^{\circ} \mathrm{C}$, then the solid residue was dissolved in EtOAc and the mixture stirred for $5 \mathrm{~min}$. The catalyst was recovered. Then solvent was evaporated, the remaining solid product was recrystallized in aqueous EtOH (15\%).

All products are known and compounds were characterized by melting point (mp), ${ }^{1} \mathrm{H}-\mathrm{NMR},{ }^{13} \mathrm{C}-\mathrm{NMR}$ and FT-IR and MS. Some physical data of these compounds are represented below:

2.2a N-[Phenyl-(2-hydroxy-naphthalen-1-yl)-methyl]acetamide (table 2, entry 1): White solid; M.p.<smiles>CC(N)=O</smiles>

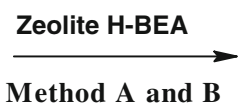<smiles>CC(=O)NC(c1ccccc1)c1c(O)ccc2ccccc12</smiles>

Method A: Under toluene reflux

Method B: Thermal Solvent-Free conditions

Scheme 1. 
244-245 ${ }^{\circ}$; ${ }^{1} \mathrm{H}$ NMR (DMSO-d6): $\delta=1.98(s, 3 \mathrm{H})$, 7.18-1.10 (m, 4H), 7.25-7.20 (m, 4H), $7.33(t$, $\mathrm{J}=7.5 \mathrm{~Hz}, 1 \mathrm{H}), 7.74(\mathrm{~d}, \mathrm{~J}=9.2 \mathrm{~Hz}, 1 \mathrm{H}),, 7.81(d$, $\mathrm{J}=8.0 \mathrm{~Hz}, 1 \mathrm{H}), 7.84(s, 1 \mathrm{H}), 8.46(d, \mathrm{~J}=8.5 \mathrm{~Hz}, 1 \mathrm{H})$, $10.02(s, 1 \mathrm{H}) \mathrm{ppm} ;{ }^{13} \mathrm{C}$ NMR $(125 \mathrm{MHz}$, DMSO-d6): 23.3, 40.1, 119.2, 119.4, 122.4, 123.8, 126.6, 126.9, 128.4, 128.6, 128.9, 129.1, 129.8, 132.9, 143.1, 153.7, 168.9 ppm; IR (KBr): 3400, 3250, 3063, 1640, 1581, $1514,1372,1337,1060,808,742,696,623 \mathrm{~cm}^{-1}$; MS $m / z: 292\left([\mathrm{M}+\mathrm{H}]^{+}\right)$.

$2.2 \mathrm{~b} \quad \mathrm{~N}$-[(4-Methylphenyl)-(2-hydroxynapthalen-1yl)-methyl]-acetamide (table 2, entry 2): M.p. 222$224{ }^{\circ} \mathrm{C} ;{ }^{1} \mathrm{H}$ NMR (DMSO-d6): $\delta=1.96$ (s, 3H), 2.21(s, $3 \mathrm{H}), 7.08-7.03(\mathrm{~m}, 5 \mathrm{H}), 7.19(\mathrm{~d}, J=8.8 \mathrm{~Hz}, 1 \mathrm{H}), 7.24(\mathrm{t}$, $J=7.1 \mathrm{~Hz}, 1 \mathrm{H}), 7.34(\mathrm{~m}, 1 \mathrm{H}), 7.74(\mathrm{~d}, J=8.8 \mathrm{~Hz}$, $1 \mathrm{H}), 7.78(\mathrm{~d}, J=7.9 \mathrm{~Hz}, 1 \mathrm{H}), 7.82(\mathrm{brd}, 1 \mathrm{H}), 8.36(\mathrm{~d}$, $J=8.1 \mathrm{~Hz}, 1 \mathrm{H}), 9.91(\mathrm{~s}, 1 \mathrm{H}) \mathrm{ppm} ;{ }^{13} \mathrm{C} \mathrm{NMR}(125 \mathrm{MHz}$, DMSO-d6): 20.4, 22.6, 47.6, 118.4, 118.9, 122.2, 123.1, 125.9, 126.1, 128.3, 128.4, 128.9, 132.2, 134.9, 139.4, 143.3, 152.9, 168.9 ppm.; IR (KBr): 3419, 3316, 3070, 1621, 1595, 1561, 1514, 1466, 1392, 1283, 1202, 1141, 1051, 939, 884, 784, 745, $712 \mathrm{~cm}^{-1}$; MS $\mathrm{m} / z$ : $305\left([\mathrm{M}+\mathrm{H}]^{+}\right)$; Anal. Calcd. for $\mathrm{C} 20 \mathrm{H} 19 \mathrm{NO} 2$ : C: 78.66; H: 6.27; N: $4.59 \%$. Found: C: 78.75; H: 6.19; N: $4.62 \%$.

2.2c N-[(4-Methoxy-phenyl)-(2-hydroxy-napthalen-1yl)- methyl]-acetamide (table 2, entry 9) M.p. 181$183^{\circ} \mathrm{C}:{ }^{1} \mathrm{H}$ NMR (DMSO-d6): $\delta=10(\mathrm{~s}, 1 \mathrm{H}), 8.4(\mathrm{~d}$, 1H), 7.80-7.73 (m, 4H), 7.35-7.05 (m, 6H), 2.51 (s, 3H), 1.94 (s, 3H). IR (KBr): 3399, 3063, 3000, 2964, 2830, 2785, 2704, 1626, 1581, 1514, 1438, 1372, 1337, 1280, 1257, 1180, 1086, 1060, 1045, 928, 879, 847, $820,746 \mathrm{~cm}^{-1} ; \mathrm{MS} m / z: 322\left([\mathrm{M}+\mathrm{H}]^{+}\right)$. 2.2d N-[(2-Chloro-phenyl)-(2-hydroxy-napthalen-1-yl)methyl]-acetamide (table 2, entry 11) M.p. $213-215^{\circ} \mathrm{C}::$ ${ }^{1} \mathrm{H}$ NMR (DMSO-d6): $\delta=1.91$ (s, 3H), 7.08-7.56 (m, $8 \mathrm{H}), 7.73(\mathrm{~d}, \mathrm{~J}=7.6 \mathrm{~Hz}, 1 \mathrm{H}), 7.78(\mathrm{~d}, \mathrm{~J}=6.1 \mathrm{~Hz}, 1 \mathrm{H})$, $8.00(\mathrm{t}, \mathrm{J}=7.0 \mathrm{~Hz}, 1 \mathrm{H}), 8.50(\mathrm{~s}, 1 \mathrm{H}), 9.75(\mathrm{~s}, 1 \mathrm{H}) \mathrm{ppm}$; IR (KBr): 3427, 3061, 1640, 1514, 1438, 1268, 808, $752,501 \mathrm{~cm}^{-1}$; MS $m / z: 325\left([\mathrm{M}+\mathrm{H}]^{+}\right)$.

\section{Results and discussion}

In order to carry out synthesis of amidoalkyl naphthol in a more efficient way that minimizes time and the amount of catalyst, the reaction of 2-naphthol, benzaldehyde and acetamide was selected as a model reaction. The best result was obtained by carrying out the reaction with 1:1:1.2 molar ratios of 2-naphthol, benzaldehyde acetamide and $7 \mathrm{wt} \%$ of zeolite H-BEA. Further, looking towards the \% yield $(85 \%)$ and shorter reaction time (5-7 $\mathrm{min})$, thermal solvent-free condition is found to be more beneficial compared to the solvent reflux condition (table 1).

Thus, we have made an attempt to prepare a range of amidoalkyl naphthols under the optimized reaction conditions i.e., 2-naphthol ( $1 \mathrm{mmol})$, aryl aldehydes $(1 \mathrm{mmol})$, and acetamide $(1.2 \mathrm{mmol})$ in the presence of zeolite H-BEA (7 wt\%). A series of amidoalkyl naphthols were prepared in high to excellent yields in thermal solvent-free conditions (table 2). In all cases, aromatic aldehydes with substituents carrying either electron-donating or electron-withdrawing groups gave the desired products in Method A and B with yield of 70-90\%. The XRD patterns of zeolite before and after the reaction revealed that the zeolite retained its crystallinity throughout. Thus, the catalyst can be reused. Further, the catalysts were recycled for five runs without significant loss of activity (figure 2).

Table 1. Optimization of catalyst concentration. ${ }^{\text {a }}$

\begin{tabular}{lcccccc}
\hline \multirow{2}{*}{ Entry } & \multirow{2}{*}{ H-BEA } & \multicolumn{2}{c}{ Reflux condition } & & \multicolumn{2}{c}{ Thermal solvent-free condition } \\
\cline { 3 - 4 } \cline { 6 - 7 } & & Time (h) & Yield (\%) & & Time (min) & Yield $(\%)$ \\
\hline 1 & 2 wt \% & $10-11$ & 55 & & $10-15$ & 61 \\
2 & 5 wt \% & $7-9$ & 69 & & $9-10$ & 75 \\
3 & 7 wt \% & $\mathbf{4 - 6}$ & $\mathbf{7 8}$ & & $\mathbf{5 - 7}$ & $\mathbf{8 5}$ \\
4 & 10 wt \% & $4-6$ & 70 & & $5-7$ & 79 \\
5 & 15 wt \% & $4-6$ & 72 & & $5-7$ & 73 \\
\hline
\end{tabular}

${ }^{\text {a}}$ Reaction condition:

2-naphthol/aldehyde/acetamide (1/1/1.2) under toluene reflux,

2-naphthol/aldehyde/acetamide/catalyst (1/1/1.2) under thermal solvent-free condition, oil bath, $120^{\circ} \mathrm{C}$

${ }^{\mathrm{b}}$ Yields refers to the pure isolated products 
Table 2. Synthesis of amidoalkyl naphthols using zeolite H-BEA. ${ }^{a}$

\begin{tabular}{llc}
\hline Entry & \multicolumn{1}{c}{ Aldehydes } & Time $(\min ) /$ yield $(\%)^{\mathrm{c}}$ \\
\hline 1 & $\mathrm{C}_{6} \mathrm{H}_{5} \mathrm{CHO}$ & $5-7 / 85$ \\
2 & $4-\mathrm{Me} \mathrm{C}_{6} \mathrm{H}_{4} \mathrm{CHO}$ & $5-7 / 73$ \\
3 & $4-\mathrm{NO}_{2}-\mathrm{C}_{6} \mathrm{H}_{4} \mathrm{CHO}$ & $5-7 / 90$ \\
4 & $4-\mathrm{NMe}_{2} \mathrm{C}_{6} \mathrm{H}_{3} \mathrm{CHO}$ & $5-7 / 70$ \\
5 & $4-\mathrm{Cl}-\mathrm{C}_{6} \mathrm{H}_{4} \mathrm{CHO}$ & $5-7 / 80$ \\
6 & $4-\mathrm{Br}_{6} \mathrm{C}_{6} \mathrm{H}_{4} \mathrm{CHO}$ & $5-7 / 82$ \\
7 & $4-\mathrm{F}-\mathrm{C}_{6} \mathrm{H}_{4} \mathrm{CHO}$ & $5-7 / 78$ \\
8 & $2,4-\mathrm{Cl}_{2}-\mathrm{C}_{6} \mathrm{H}_{3} \mathrm{CHO}$ & $5-7 / 80$ \\
9 & $4-\mathrm{MeOC}_{6} \mathrm{H}_{4} \mathrm{CHO}$ & $5-7 / 82$ \\
10 & $3-\mathrm{MeO}_{6} \mathrm{H}_{4} \mathrm{CHO}$ & $5-7 / 80$ \\
11 & $2-\mathrm{Cl}_{-} \mathrm{C}_{6} \mathrm{H}_{4} \mathrm{CHO}$ & $5-7 / 76$ \\
12 & $2-\mathrm{NO}_{2}-\mathrm{C}_{6} \mathrm{H}_{4} \mathrm{CHO}$ & $5-7 / 80$ \\
13 & $\mathrm{C}_{6} \mathrm{H}_{5} \mathrm{CH}_{4} \mathrm{CHCHO}_{10}$ & $5-7 / 65$ \\
14 & $\mathrm{CH}_{3} \mathrm{CHO}_{2}$ & $10 /-$ \\
15 & $\mathrm{CH}_{3}\left(\mathrm{CH}_{2}\right)_{2} \mathrm{CHO}$ & $10 /-$ \\
\hline
\end{tabular}

${ }^{\text {a }}$ Reaction conditions:

2-naphthol/aldehyde/acetamide/catalyst (1/1/1.2/7 wt\%) under thermal solvent-free condition, oil bath, $120^{\circ} \mathrm{C}$

${ }^{\mathrm{b}}$ Yields refer to the pure isolated products

${ }^{\mathrm{c}}$ All known products have been reported previously in the literature and were characterized by comparison of IR and NMR spectra with authentic samples. ${ }^{13-19}$

The proposed mechanism for the H-BEA catalysed preparation of amidoalkyl naphthols from the reaction of 2-naphthol, aromatic aldehydes and acetamide under reflux and thermal conditions is shown in scheme 2 .

As can be seen from the results (table 2), this reaction is affected by electronic and steric factors. Aldehydes with electron-withdrawing groups, gave higher yields than those with electron-donating groups. A reasonable explanation for this result has been suggested<smiles>Oc1ccc2ccccc2c1</smiles>

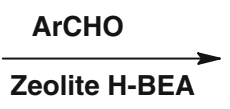<smiles>CC(=O)NC([Al])c1c(O)ccc2ccccc12</smiles><smiles>O=CC=C1C(=O)C=Cc2ccccc21</smiles>

O-QMs

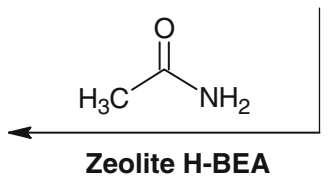

Scheme 2.

by Shaterian et al. ${ }^{13}$ The condensation of 2-naphthol with aldehydes under acid catalysts gave ortho-quinone methides (o-QMs). The generated o-QMs reacted with acetamide via the conjugated addition to afford 1amidoalkyl-2-naphthols. Electron-withdrawing groups on the benzaldehydes in the o-QMs increase the rate of the 1,4-nucleophilic addition reaction because the alkene LUMO is at lower energy in the presence of electron-withdrawing groups compared with electrondonating groups. Ortho substituents decrease the yield of the reaction probably due to the steric effect (table 2, entry 11,12$)$. The scope of the reaction was also investigated with aliphatic aldehydes and $\alpha, \beta$-unsaturated aldehydes. In our preliminary attempts with aliphatic aldehydes ${ }^{13}$ such as acetaldehyde and butyraldehyde (table 2, entry 14 and 15 respectively) the reaction failed to yield the corresponding amidoalkyl naphthols. However, in case of $\alpha, \beta$-unsaturated aldehydes i.e., cinnamaldehyde, we have isolated the product, amidoalkyl naphthol along with impurity (table 2, entry 13). In

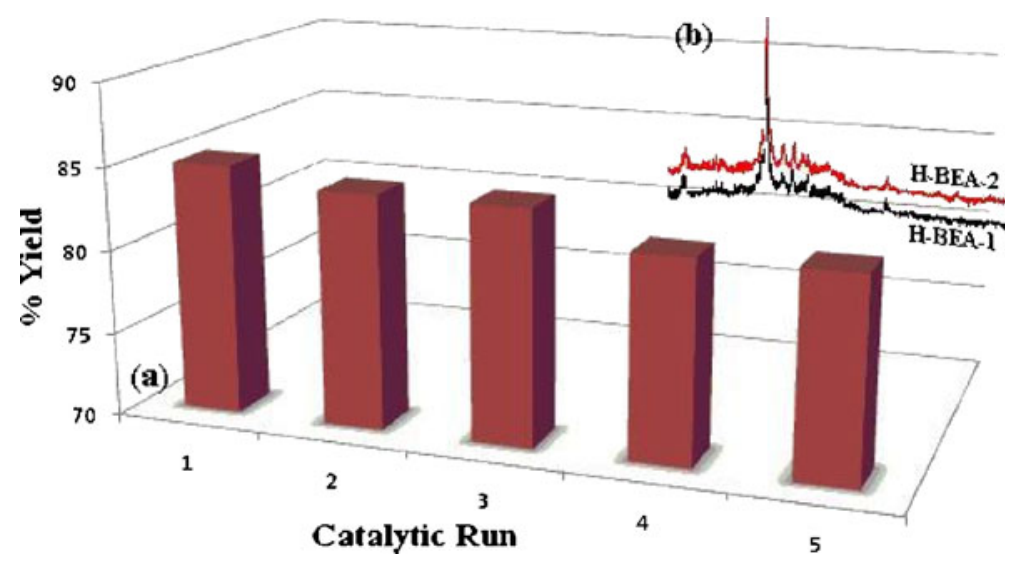

Figure 2. (a) Recyclability of zeolite H-BEA, (b) XRD patterns of H-BEA before used (H-BEA-1) and after four run (H-BEA-2). 


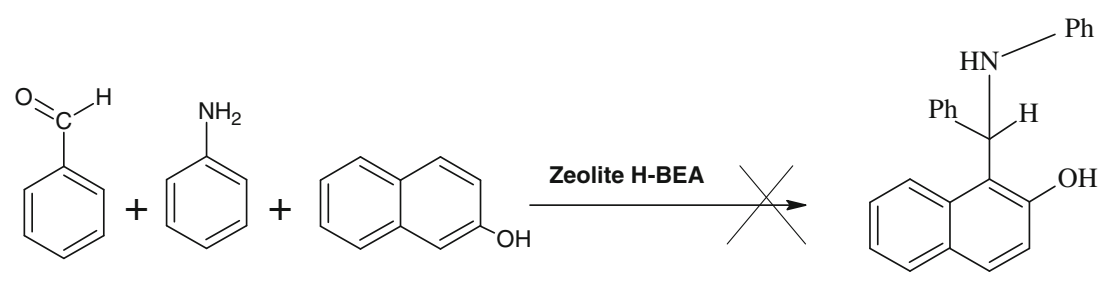

Scheme 3.

Table 3. Comparison of catalytic activity of H-BEA with several catalysts for synthesis of amidoalkyl naphthol.

\begin{tabular}{|c|c|c|c|c|c|}
\hline Entry & Catalyst & Time & Solvent (temp) & Yield $(\%)$ & Ref \\
\hline 1 & Montmorillonite K-10 clay & $1 \mathrm{~h}$ & $-\left(125^{\circ} \mathrm{C}\right)$ & 84 & [4] \\
\hline 2 & $\mathrm{HClO}_{4}-\mathrm{SiO}_{2}$ & $40 \mathrm{~min}$ & $-\left(110^{\circ} \mathrm{C}\right)$ & 89 & [5] \\
\hline 3 & $\mathrm{I}_{2}$ & $4.5 \mathrm{~h}$ & $-\left(125^{\circ} \mathrm{C}\right)$ & 87 & [7] \\
\hline 4 & $\mathrm{~K}_{5} \mathrm{CoW}_{12} \mathrm{O}_{40} 3 \mathrm{H} 2 \mathrm{O}$ & $2 \mathrm{~h}$ & $-\left(125^{\circ} \mathrm{C}\right)$ & 90 & [8] \\
\hline 5 & $\mathrm{NaHSO}_{4}$ & $20 \mathrm{~h}$ & $\mathrm{ACN}\left(85^{\circ} \mathrm{C}\right)$ & 80 & {$[13]$} \\
\hline 6 & $\mathrm{Fe}\left(\mathrm{HSO}_{4}\right)_{3}$ & $50 \mathrm{~min}$ & $-\left(85^{\circ} \mathrm{C}\right)$ & 93 & [14] \\
\hline 7 & Wet TCT (Cyanuric chloride) & $10 \mathrm{~min}$ & $-\left(100^{\circ} \mathrm{C}\right)$ & 91 & {$[15]$} \\
\hline 8 & {$[\mathrm{TEBSA}]\left[\mathrm{HSO}_{4}\right]$ (Bronsted acidic Ionic liquid) } & $10 \min$ & $-\left(120^{\circ} \mathrm{C}\right)$ & 87 & [16] \\
\hline 9 & $\mathrm{FeCl}_{3}-\mathrm{SiO}_{2}$ & $11 \mathrm{~min}$ & $-\left(120^{\circ} \mathrm{C}\right)$ & 86 & {$[17]$} \\
\hline 10 & H-BEA & $4-6$ & Tolune $\left(110^{\circ} \mathrm{C}\right)$ & 78 & This work \\
\hline 11 & H-BEA & $5-7 \mathrm{~min}$ & $-\left(120^{\circ} \mathrm{C}\right)$ & 90 & This work \\
\hline
\end{tabular}

Table 4. Characterization of zeolite.

\begin{tabular}{lccccccr}
\hline Catalysts & $\begin{array}{c}\text { Channel } \\
\text { structure }\end{array}$ & $\begin{array}{c}\text { Pore } \\
\text { structure }(\mathrm{nm})\end{array}$ & $\begin{array}{c}\mathrm{SiO}_{2} / \mathrm{Al}_{2} \mathrm{O}_{3} \\
\text { ratio }\end{array}$ & $\begin{array}{c}\mathrm{S}_{\mathrm{BET}} \\
\left(\mathrm{m}^{2} / \mathrm{g}\right)\end{array}$ & \multicolumn{2}{c}{ Ammonia uptake (mmol/g) } \\
\cline { 6 - 8 }
\end{tabular}

our laboratory, we have been working in the direction to optimize the yield of amidoalkyl naphthols using various conjugated aldehydes. On the other hand, the reactions with thiourea were considered, but no corresponding products were produced. Also, amine such as aniline was utilized and no aminoalkyl naphthol was obtained (scheme 3 ).

Moreover, table 3 shows the merit of the present work in comparison with the results reported in the literature. The results revealed that zeolite $\mathrm{H}$-BEA can act as an effective catalyst with respect to reaction times, yields and the obtained products. The efficiency of zeolite $\mathrm{H}-$ BEA towards these reactions can be explained by the various physiochemical parameters (table 4) as it possess higher surface area and weak to moderate acidity which are the prime factor for higher catalytic activity of zeolite catalyst. Further, the loss of 10-20\% yields in these reactions are probably ascribed to geometry of zeolite catalyst as restricted pore architecture of zeolite $(\mathrm{BEA}-0.76 \times 0.64 \mathrm{~nm}$, table 4$)$ sometimes limiting the diffusion of bulkier reactant molecules as well as geometrical constraints for the formation of intermediates inside the pores. Moreover, we observed that solid aldehydes are reacted smoothly where as trace amount of liquid aldehydes were found unreacted during the reaction.

\section{Conclusion}

In conclusion, we demonstrated a new application of zeolite H-BEA in the synthesis of amidoalkyl naphthols. A series of amidoalkyl naphthols were obtained in high yields via three-component reaction of 2-naphthol, aromatic aldehydes and amide under two different conditions (Method A and B). The thermal solvent-free 
(Method B) green procedures offer advantages such as shorter reaction times, simple work-up, environmentally benign, excellent yield, cost effective recovery and reusability of catalyst for a number of times without significant loss of activity. Further applications of zeolite in organic transformations are currently in progress in our laboratories.

\section{Acknowledgements}

The authors thank the Applied Chemistry Department, Sardar Vallabhbhai National Institute of Technology, Surat for providing research facility.

\section{References}

1. Holderich W F and Bekkum H V 2001 Stud. Surf. Sci. Catal. 137821

2. Ram Reddy P, Subba Rao K V and Subrahmanyam M 1998 Catal. Lett. 56158

3. Dallinger D, Stadler A and Kappe C O 2004 Pure Appl. Chem. 761017

4. (a) Dinermann T, Steinhilber D and Folkers G 2004 Molecular biology in medicinal chemistry (WileyVCH); (b) Shen A Y, Tsai C T and Chen C L 1999 Eur. J. Med. Chem. 34877
5. Kantevari S, Vuppalapati S V N and Nagarapu L 2007 Catal. Commun. 81857

6. Shaterian H R, Yarahmadi H and Ghashang M 2008 Tetrahedron. 641236

7. Das B, Laxminarayana K, Ravikanth B and Rao B R 2007 J. Mol. Catal. A: Chem. 261180

8. (a) Nagarapu L, Baseeruddin M, Apuri S and Kantevari S 2007 Catal. Commun. 8 1729; (b) Supale A R and Gokavi G S 2010 J. Chem. Sci. 122192

9. Khodaei M M, Khosropour A R and Moghanian H 2006 Synlett. 6916

10. Patil S B, Singh P R, Surpur M P and Samant S D 2007 Ultrason. Sonochem. 14515

11. Patil S B, Singh P R, Surpur M P and Samant S D 2007 Synth. Commun. 371659

12. Clark J H 1999 Green Chem. 11

13. Shaterian H R and Yarahmadi H 2008 Arkivoc. 2105

14. Shaterian H R, Yarahmadi H and Ghashang M 2008 Bioorg. Med. Chem. Lett. 18788

15. Mahdavinia G H and Bigdeli M A 2009 Chin. Chem. Lett. 20386

16. Hajipour A R, Ghayeb Y, Sheikhan N and Ruoho A E 2009 Tetrahedron Lett. 505651

17. Shaterian H R and Yarahmadi H 2008 Tetrahedron Lett. 491297

18. Anilkumar, Sudershan Rao M, Ahmad I and Khungar B 2009 Can. J. Chem. 87714

19. Gawanda P, Deokara H, Langia B, Yadav A, Chaskara A and Thakur C K 2009 Synth. Commun. 394171 